\title{
Expression and Functions of the $\mathrm{CB}_{2}$ Receptor in Human Leukocytes
}

\author{
Mélissa Simard ${ }^{1,2}$, Volatiana Rakotoarivelo ${ }^{1,2}$, Vincenzo Di Marzo ${ }^{1,2,3,4,5}$ and \\ Nicolas Flamand ${ }^{1,2 *}$
}

${ }^{1}$ Centre de Recherche de l'Institut Universitaire de Cardiologie et de Pneumologie de Québec, Département of Médecine, Faculté de Médecine, Université Laval, Québec City, QC, Canada, ${ }^{2}$ Canada Excellence Research Chair on the MicrobiomeEndocannabinoidome Axis in Metabolic Health (CERC-MEND), Université Laval, Québec City, QC, Canada, ${ }^{3}$ Endocannabinoid Research Group, Institute of Biomolecular Chemistry, Consiglio Nazionale Delle Ricerche (CNR), Pozzuoli, Italy, ${ }^{4}$ Institut sur la Nutrition et les Aliments Fonctionnels, Centre NUTRISS, École de Nutrition, Faculté des Sciences de L'agriculture et de L'alimentation, Université Laval, Québec City, QC, Canada, ${ }^{5}$ Joint International Unit Between the Consiglio Nazionale Delle Ricerche (Italy) and Université Laval (Canada) on Chemical and Biomolecular Research on the Microbiome and Its Impact on Metabolic Health and Nutrition (UMI-MicroMeNu), Naples, Italy

OPEN ACCESS

Edited by:

Pal Pacher,

National Institute on Alcohol Abuse and Alcoholism (NIAAA), United States

Reviewed by:

Valeria Gasperi,

University of Rome Tor Vergata, Italy

${ }^{*}$ Correspondence:

Nicolas Flamand

Nicolas.Flamand@criucpq.ulaval.ca

Specialty section:

This article was submitted to

Experimental Pharmacology and Drug

Discovery,

a section of the journal

Frontiers in Pharmacology

Received: 30 November 2021

Accepted: 14 January 2022

Published: 22 February 2022

Citation:

Simard M, Rakotoarivelo V, Di Marzo V and Flamand $N$ (2022) Expression and

Functions of the $\mathrm{CB}_{2}$ Receptor in

Human Leukocytes.

Front. Pharmacol. 13:826400.

doi: 10.3389/fphar.2022.826400
The cannabinoid $\mathrm{CB}_{2}$ receptor was cloned from the promyeloid cell line HL-60 and is notably expressed in most, if not all leukocyte types. This relatively restricted localization, combined to the absence of psychotropic effects following its activation, make it an attractive drug target for inflammatory and autoimmune diseases. Therefore, there has been an increasing interest in the past decades to identify precisely which immune cells express the $\mathrm{CB}_{2}$ receptor and what are the consequences of such activation. Herein, we provide new data on the expression of both $\mathrm{CB}_{1}$ and $\mathrm{CB}_{2}$ receptors by human blood leukocytes and discuss the impact of $\mathrm{CB}_{2}$ receptor activation in human leukocytes. While the expression of the $\mathrm{CB}_{2}$ mRNA can be detected in eosinophils, neutrophils, monocytes, $\mathrm{B}$ and $\mathrm{T}$ lymphocytes, this receptor is most abundant in human eosinophils and $\mathrm{B}$ lymphocytes. We also review the evidence obtained from primary human leukocytes and immortalized cell lines regarding the regulation of their functions by the $\mathrm{CB}_{2}$ receptor, which underscore the urgent need to deepen our understanding of the $\mathrm{CB}_{2}$ receptor as an immunoregulator in humans.

Keywords: CB2 receptor, eosinophil, neutrophil, monocyte, lymphocyte, inflammation, asthma, allergy

\section{INTRODUCTION}

The cannabinoid receptors 1 and $2\left(\mathrm{CB}_{1}\right.$ and $\left.\mathrm{CB}_{2}\right)$ are two $\mathrm{G}$ protein-coupled receptors that function through binding a vast array of ligands including phytocannabinoids and endocannabinoids (Di Marzo et al., 1998; Turcotte et al., 2015). The $\mathrm{CB}_{1}$ receptor, highly expressed in the brain, was the first cannabinoid receptor identified through its responsiveness to $\Delta^{9}$-tetrahydrocannabinol $\left(\Delta^{9}\right.$-THC) and cloned (Devane et al., 1988; Matsuda et al., 1990). Its activation induces psychotropic effects and its involvement shown in, among others, motor function, cognition and memory (Howlett and Abood 2017). It is also widely recognized as worsening obesity and related diseases (Di Marzo 2018). The $\mathrm{CB}_{2}$ receptor was later cloned from HL-60 cells and identified on its $44 \%$ aminoacid homology with the $\mathrm{CB}_{1}$, as well as its similar binding profile to the endocannabinoid $\mathrm{N}$-arachidonoylethanolamine (AEA) and $\Delta^{9}$-THC (Munro et al., 1993). Soon after, Galiègue et al. documented that it was expressed by human leukocytes (Galiegue et al., 1995). This consolidated the concept that the $\mathrm{CB}_{2}$ is the peripheral cannabinoid receptor and, for many, the inflammatory cannabinoid receptor. In fact, the $\mathrm{CB}_{2}$ receptor has been found in all leukocyte populations tested so far [see 

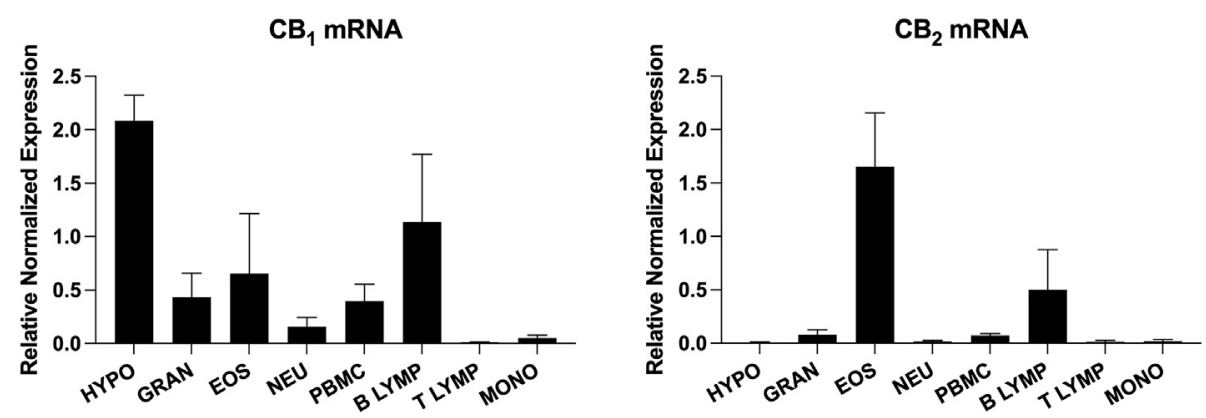

FIGURE 1 | Expression of the $\mathrm{CB}_{1}$ and $\mathrm{CB}_{2}$ receptors mRNA in human leukocytes isolated from the blood. Human venous blood was collected from healthy volunteers with the informed consent of all participants in blood collection tubes containing $\mathrm{K}_{3}$ EDTA as anticoagulant. Granulocytes (GRAN), eosinophils (EOS) and neutrophils (NEU) were isolated as in Chouinard et al. (2013). PBMCs were obtained from the PBMC layer and taken as is or otherwise processed for monocyte (MONO), B and T lymphocytes (LYMP) isolation using the EasySep ${ }^{\mathrm{TM}}$ monocyte isolation kit, CD19 positive Selection Kit II and CD3 positive selection Kit II respectively, as per the manufacturer's protocol. Purity of the different isolated leukocytes was always $>97 \%$ with the exception of B Lymphocytes (90\%) with MONO being the main contaminant. Hypothalamus (HYPO) samples were obtained from the Douglas-Bell Canada Brain Bank (McGill University, Montréal, Canada). mRNA was next isolated from the different preparations with TRIzol as per the manufacturer's protocol. 500 ng of total RNA was reverse transcribed using a High-Capacity cDNA Reverse Transcription Kit (Applied Biosystems, CA, USA) as recommended. qPCR analyses were finally performed on a CFX Connect Real-Time PCR System, using the following primers (forward - reverse): GAPDH (5'-ACATCGCTCAGACACCATG-3'-5'-TGTAGTTGAGGTCAATGAAGGG-3') 18S (5'-CGCACGGCCGGTACAGTGAA-3'-5' GGGAGAGGAGCGAGCGACCA-3') CB 1 (5'-TTCCCTCTTGTGAAGGCACTG-3'-5'-TCTTGACCGTGCTCTTGATGC-3') and CB 2 (5'-CAAGGCTGTCTTCCTGCTGA$3^{\prime}-5^{\prime}$-CGGGTGAGCAGAGCTTTGTA-3'). Data represent the mean ( \pm SEM) of 4-6 donors and was obtained using the CFX Maestro Software (Bio-Rad).

(Turcotte et al., 2016) for a review]. However, $\mathrm{CB}_{2}$ receptor expression is not restricted to leukocytes. It has notably been found in resident immune brain cells (microglia), the kidney, spleen, tonsil, thymus, lung epithelial cells and testes (Sanchez et al., 2001; Brown et al., 2002; Van Sickle et al., 2005; EllertMiklaszewska et al., 2007; Zhou et al., 2018; Cakir et al., 2019; Fantauzzi et al., 2020).

\section{EXPRESSION OF THE CB $_{1}$ AND CB $_{2}$ RECEPTORS BY HUMAN BLOOD LEUKOCYTES}

Galiègue et al. paved the way to our understanding of $\mathrm{CB}_{2}$ expression by human leukocytes by showing its mRNA was expressed in human leukocytes, with the following order of relative abundance: tonsillar $\mathrm{B}$ cells $>$ natural killer cells $>$ monocytes $\sim$ granulocytes $>$ T4 lymphocytes $>$ T8 lymphocytes (Galiegue et al., 1995). While very informative and useful, the data from Galiègue et al. did not include eosinophils while including tissue instead of blood B lymphocytes. This was somewhat pointed out in following studies (Turcotte et al., 2016), as it might have led to some inconsistencies. For example, while some documented the expression of the $\mathrm{CB}_{2}$ receptor in human granulocytes (neutrophils and contaminating eosinophils) (Galiegue et al., 1995; Kurihara et al., 2006), others did not (Oka et al., 2004; Graham et al., 2010). This raised the possibility that contaminating cells might have been responsible for the previously documented $\mathrm{CB}_{2}$ signal in neutrophils, and possibly other cell types. Noteworthy, it was later reported that eosinophildepleted neutrophils weakly expressed the $\mathrm{CB}_{2}$ receptor mRNA, while eosinophils (the main neutrophil suspension contaminant) expressed it at high levels, raising the strong possibility that discrepancies regarding $\mathrm{CB}_{2}$ expression in neutrophils could be the result of contaminating eosinophils in granulocyte preparations (Chouinard et al., 2013). $\mathrm{CB}_{2}$ expression was also reported in human eosinophils in other studies (Frei et al., 2016; Larose et al., 2017; Freundt-Revilla et al., 2018; Dothel et al., 2019).

In an attempt to better define $\mathrm{CB}_{2}$ expression in human blood leukocytes, we revisited its expression by qPCR using mRNA from leukocytes that were isolated from the blood of healthy volunteers. $\mathrm{CB}_{1}$ receptor expression was assessed in parallel. Hypothalamus samples were utilized as positive controls for the $\mathrm{CB}_{1}$ receptor. In our hands, all tested leukocytes expressed the $\mathrm{CB}_{1}$ receptor mRNA although to a lesser extent than hypothalamus samples (Figure 1A). In contrast, while we detected the expression of the $\mathrm{CB}_{2}$ receptor mRNA in all leukocyte and hypothalamus samples, human eosinophils and B lymphocytes displayed the strongest signals (Figure 1B). Thus, these cell types are likely the origin of $\mathrm{CB}_{2}$ expression found in mixed populations such as granulocytes (neutrophils and eosinophils, often abbreviated as PMN) and PBMCs (monocytes, $\mathrm{B}$ and $\mathrm{T}$ lymphocytes). This underlines the importance of separating granulocytes and PBMCs when studying the $\mathrm{CB}_{2}$ receptor. The small, but detectable levels of $\mathrm{CB}_{2}$ receptor mRNA in hypothalamus samples are consistent with other studies reporting its expression in this tissue (Sanchez et al., 2001; Van Sickle et al., 2005; Ellert-Miklaszewska et al., 2007).

\section{FACTORS INFLUENCING CB $_{2}$ RECEPTOR EXPRESSION IN HUMAN LEUKOCYTES}

Some factors were documented as influencing $\mathrm{CB}_{2}$ receptor expression in human leukocytes. $\mathrm{CB}_{2}$ expression can increase 
during inflammation as it is the case in eosinophils from symptomatic allergic donors compared to healthy controls (Frei et al., 2016; Larose et al., 2017), in monocytes of patients after ischemic stroke (Greco et al., 2021), in myeloid and plasmacytoid dendritic cells of patients with multiple sclerosis (Chiurchiu et al., 2013; Sanchez Lopez et al., 2015) and in T lymphocytes of Non-Hodgkin's lymphomas (Rayman et al., 2007; Robinson et al., 2013). On the other hand, LPS decreased $\mathrm{CB}_{2}$ receptor expression in isolated dendritic cells and $\mathrm{B}$ lymphocytes (Lee et al., 2001; Do et al., 2004). Finally, the $\mathrm{CB}_{2}$ receptor was not detected in resting macrophages, was present at high levels in responsive and primed cells and was greatly diminished in fully activated cells (Cabral 2010). The latter observation suggests that the $\mathrm{CB}_{2}$ receptor might have a time-specific function in macrophages during inflammation.

Numerous $\mathrm{CB}_{2}$ receptor antibodies have been developed but most (if not all) are failing to provide reliable signals in different applications (immunohistochemistry, cytofluorometry and immunoblot), while not always having been characterized with the appropriate controls (control peptide blockade, $\mathrm{CB}_{2}$ receptordevoid cells, cross reactivity). Thus, until a clear consensus is achieved on which antibodies are sufficiently reliable, data on $\mathrm{CB}_{2}$ protein should be interpreted with caution. With that in mind, the $\mathrm{CB}_{2}$ receptor protein localization can vary. Indeed, Castaneda et al. reported that the $\mathrm{CB}_{2}$ receptor protein was found intracellularly in most leukocytes with only $\mathrm{B}$ lymphocytes expressing it at the extracellular membrane (Castaneda et al., 2013). $\mathrm{CB}_{2}$-positive $\mathrm{B}$ lymphocytes were mainly located in the mantle of secondary lymphoid follicles, which contain immature B lymphocytes while some positive cells also appeared in the germinal centers of secondary follicles, which contain mature B lymphocytes, suggesting an heterogeneous distribution of the receptor during B lymphocytes maturation stages (Galiegue et al., 1995). Immunohistochemical analysis using an $\mathrm{N}$-terminal specific anti- $\mathrm{CB}_{2}$ antibody revealed high protein expression in the germinal centers of secondary follicles while a C-terminal specific anti- $\mathrm{CB}_{2}$ antibody (only recognizing a nonphosphorylated inactive receptor) showed positivity primary follicle, the mantle and marginal zones of the secondary follicles where resting cells reside (Rayman et al., 2004). Therefore, active $\mathrm{CB}_{2}$ seems mainly present on $\mathrm{B}$ lymphocytes in the germinal centers.

\section{IMPACT OF $\mathrm{CB}_{2}$ RECEPTOR ACTIVATION IN HUMAN LEUKOCYTES}

The early studies investigating the roles of the $\mathrm{CB}_{2}$ receptor, notably those involving cnr2-deficient mice, led to the idea that it is mainly anti-inflammatory (Turcotte et al., 2016). However, recent studies are emerging and indicate that the outcome of $\mathrm{CB}_{2}$ receptor signaling may differ depending on the experimental model/disease. A good example is experimental asthma. Indeed, early work indicated that the $\mathrm{CB}_{2}$ receptor agonist WIN 55,212-2 inhibited ovalbumin-induced plasma extravasation in guinea pig airways (Fukuda et al., 2010). In contrast, the $\mathrm{CB}_{2}$ receptor agonist JWH-133 aggravated ovalbumin-induced asthma in mice while having no effect in dinitrofluorobenzene-induced asthma (Bozkurt et al., 2016; Frei et al., 2016). When house dust mites were utilized as allergen, cnr2-deficient mice were resistant to allergic responses (Ferrini et al., 2017) while an innate lymphoid cell-2 dependent model involving IL-25, IL-33 and/or Alternaria alternate had lower symptoms, decreased eosinophil number, and airway resistance (Hurrell et al., 2021). In humans, $\mathrm{CB}_{2}$ receptor expression was increased in nasal polyps of aspirinexacerbated disease patients (Corrado et al., 2018) while being decreased in epithelial cells of asthmatic patients (Fantauzzi et al., 2020).

While we address some leukocytes individually below, the overall impact of $\mathrm{CB}_{2}$ receptor activation on human leukocytes is summarized in Table 1. However, we underscore that the selectivity of the pharmacological tools targeting $\mathrm{CB}_{2}$ receptors (agonists, antagonists, inverse agonists) has been often questioned, as exemplified by the work of Soethoudt et al. (2017).

\section{Human Eosinophils}

Eosinophils participate in innate immunity against parasites and in the development/persistence of diverse inflammatory responses, notably allergies and asthma. Studies involving human eosinophils and $\mathrm{CB}$ receptors are scarce. Their treatment with either the endocannabinoid 2-AG and/or $\mathrm{CB}_{2}$ receptor agonists stimulated their migration or potentiated their migration toward other chemoattractants (Oka et al., 2004; Kishimoto et al., 2006; Larose et al., 2014; Frei et al., 2016). Importantly, these effects were prevented by the $\mathrm{CB}_{2}$ receptor antagonists $\mathrm{AM} 630$ and/or SR144528. Consistent with a $\mathrm{CB}_{2^{-}}$ mediated increased in eosinophil migration, cannabis use has been linked to some cases of acute eosinophilic pneumonia, although no demonstration has proven that this involved the $\mathrm{CB}_{2}$ receptor (Sauvaget et al., 2010; Liebling and Siu 2013; Natarajan et al., 2013; Ocal et al., 2016; Mull et al., 2020). Interestingly, while JWH-133 led to a moderate chemotactic response in human eosinophils, it had no effect on mouse eosinophils (Frei et al., 2016). Altogether, the current data support that the $\mathrm{CB}_{2}$ receptor stimulates eosinophil migration. This could eventually lead to increased parasitic defenses but also to a worsening of eosinophils-related inflammatory diseases.

\section{Human B Lymphocytes}

B lymphocytes maturation and differentiation are complex processes. Following their activation, naïve cells (spleen marginal zone) proliferate and differentiate into short-lived plasma cells, while cells from the follicles undergo massive proliferation and form germinal centers, where long-lived plasma and memory cells are formed (Basu et al., 2013). Very little is known about the role of the $\mathrm{CB}_{2}$ receptor in human $\mathrm{B}$ lymphocytes but their treatment with $\mathrm{CP} 55,940$ increased their proliferation, a phenomenon blocked by SR144528 (Carayon et al., 1998). In mice, activation of the $\mathrm{CB}_{2}$ receptor has been associated with B lymphocyte differentiation, migration, proliferation and antibody class switching (Jorda et al., 2002; Tanikawa et al., 2007; Agudelo et al., 2008), suggesting the receptor is part of the $\mathrm{B}$ lymphocytes immune programing, 
TABLE $1 \mid \mathrm{CB}_{2}$-mediated effects on human leukocytes and related human cell lines.

\begin{tabular}{|c|c|c|c|c|c|c|}
\hline $\begin{array}{l}\text { Leukocytes or } \\
\text { cell lines }\end{array}$ & $\mathrm{Ag}$ & onist & $\begin{array}{l}\text { Antagonist or } \\
\text { inverse agonist }\end{array}$ & Effects & $\begin{array}{l}\text { Impact on } \\
\text { signaling }\end{array}$ & References \\
\hline \multicolumn{7}{|l|}{ Eosinophils } \\
\hline \multirow[t]{9}{*}{ Blood } & $2-A G$ & $1 \mu \mathrm{M}(4 \mathrm{~h})$ & SR144528 (1 $\mu \mathrm{M})$ & $\begin{array}{l}\text { Induce migration in presence of } \\
1 \mu \mathrm{M} \text { NDGA (lipoxygenase } \\
\text { inhibitor) }\end{array}$ & & $\begin{array}{l}\text { Oka et al. } \\
(2004)\end{array}$ \\
\hline & & $1 \mu \mathrm{M}(1 \mathrm{~h})$ & $\mathrm{SR} 144528(1 \mu \mathrm{M})$ & $\begin{array}{l}\text { 2-AG-induced migration in } \\
\text { presence of } 1 \mu \mathrm{M} \text { NDGA is } \\
\text { attributed to chemotaxis rather } \\
\text { than chemokinesis }\end{array}$ & & $\begin{array}{l}\text { Kishimoto et al. } \\
(2006)\end{array}$ \\
\hline & & $3 \mu \mathrm{M}(2 \mathrm{~h})$ & $\begin{array}{l}\text { SR144528 } \\
(10 \mu \mathrm{M}) \\
\text { AM630 }(10 \mu \mathrm{M})\end{array}$ & $\begin{array}{l}\text { Induce migration in presence of } \\
\text { IL-5 }\end{array}$ & Inhibited by the Lyn inhibitor PP2 & $\begin{array}{l}\text { Larose et al. } \\
\text { (2014) }\end{array}$ \\
\hline & & $250 \mathrm{nM}(5 \mathrm{~h})$ & SR144528 (1 $\mu \mathrm{M})$ & $\begin{array}{l}\uparrow \text { CCL24-induced shape change } \\
\text { and migration }\end{array}$ & & $\begin{array}{l}\text { Frei et al. } \\
(2016)\end{array}$ \\
\hline & CP 55,940 & $1 \mu \mathrm{M}(2 \mathrm{~h})$ & - & No effect on migration & & $\begin{array}{l}\text { Larose et al. } \\
(2014)\end{array}$ \\
\hline & JWH-133 & $\begin{array}{l}100-250 \mathrm{nM} \\
(5 \mathrm{~h})\end{array}$ & SR144528 (1 $\mu \mathrm{M})$ & Induce migration & $\begin{array}{l}\text { Migration inhibited by MEK1 } \\
\text { inhibitors (U-0126, PD98,059) } \\
\text { and the ROCK inhibitor Y-27632 }\end{array}$ & $\begin{array}{l}\text { Frei et al. } \\
(2016)\end{array}$ \\
\hline & & & & $\begin{array}{l}\uparrow \text { CCL24-induced shape change } \\
\text { and migration }\end{array}$ & $\begin{array}{l}\text { Not inhibited by pertussis toxin } \\
\text { (PTX; G } \alpha_{i} \text {-independant), p38 or } \\
\text { PI3K inhibitors }\end{array}$ & \\
\hline & & & & $\begin{array}{l}\uparrow \text { CCL24-induced CD11b } \\
\text { upregulation }\end{array}$ & $-\uparrow \mathrm{Ca}^{2+}$ influx & \\
\hline & & & & $\uparrow$ Adhesion to ICAM-1 & $\begin{array}{l}\text { - } \mathrm{Ca}^{2+} \text { influx inhibited by the PLC } \\
\text { inhibitor U-73122 and the IP3 } \\
\text { receptor antagonist 2-APB }\end{array}$ & \\
\hline \multirow[t]{2}{*}{ Leukemia EoL-1 cells } & $2-A G$ & $1 \mu \mathrm{M}(4 \mathrm{~h})$ & $\operatorname{SR} 144528(1 \mu M)$ & $\begin{array}{l}\text { Induce migration in presence of } \\
1 \mu \mathrm{M} \text { NDGA }\end{array}$ & Inhibited by PTX (G $\mathrm{G}_{\mathrm{i} / \mathrm{O}}$-dependant) & $\begin{array}{l}\text { Oka et al. } \\
(2004)\end{array}$ \\
\hline & S-777469 & $\begin{array}{l}100-500 \mathrm{nM} \\
(4 \mathrm{~h})\end{array}$ & - & $\downarrow 2$-AG-induced migration & & $\begin{array}{l}\text { Haruna et al. } \\
(2017)\end{array}$ \\
\hline \multicolumn{7}{|l|}{ B lymphocytes } \\
\hline Blood & CP 55,940 & 1-100 nM (72 h) & $\begin{array}{l}\text { SR144528 } \\
(100-300 \mathrm{nM})\end{array}$ & $\uparrow$ Proliferation & & $\begin{array}{l}\text { Carayon et al. } \\
(1998)\end{array}$ \\
\hline \multirow[t]{2}{*}{ Tonsillar } & CP 55,940 & 1-100 nM (72 h) & $\begin{array}{l}\text { SR144528 } \\
(100-300 \mathrm{nM})\end{array}$ & $\begin{array}{l}\uparrow \text { Proliferation of both naïve and } \\
\text { germinal centrosome B } \\
\text { lymphocytes }\end{array}$ & & $\begin{array}{l}\text { Carayon et al. } \\
(1998)\end{array}$ \\
\hline & WIN 55,212-2 & $10 \mu \mathrm{M}(4 \mathrm{~h})$ & $\begin{array}{l}\text { SR144528 } \\
(10 \mathrm{nM})\end{array}$ & No effect & & $\begin{array}{l}\text { Gustafsson } \\
\text { et al. (2006) }\end{array}$ \\
\hline Raji cell line & $2-A G$ & $300 \mathrm{nM}(4 \mathrm{~h})$ & $\begin{array}{l}\text { SR144528 } \\
(100 \mathrm{nM})\end{array}$ & $\begin{array}{l}\text { Induce moderate migration } \\
\uparrow \text { Migration following stimulation } \\
\text { with an anti-sCD40 antibody }\end{array}$ & & $\begin{array}{l}\text { Rayman et al. } \\
(2004)\end{array}$ \\
\hline Rec-1 cell line & WIN 55,212-2 & $10 \mu \mathrm{M}(4 \mathrm{~h})$ & $\begin{array}{l}\text { SR144528 } \\
(10 \mathrm{nM})\end{array}$ & $\begin{array}{l}\uparrow \text { Ceramide levels (downstream } \\
\text { of p38 activation) }\end{array}$ & $\begin{array}{l}\text { - Inhibited by the } \mathrm{CB}_{1} \text { inverse } \\
\text { agonist SR141716A and by p38 } \\
\text { inhibitors } \\
\text { - Not inhibited by c-Jun or MEK-1 } \\
\text { inhibitors }\end{array}$ & $\begin{array}{l}\text { Gustafsson } \\
\text { et al. (2006) }\end{array}$ \\
\hline SKW 6.4 cell line & - & & $\begin{array}{l}\text { SR144528 } \\
(5-10 \mu \mathrm{M}) \\
\text { AM630 }(5 \mu \mathrm{M})\end{array}$ & $\begin{array}{l}\downarrow \text { IL-6 induced secretion of } \\
\text { soluble lgM } \\
\text { - } \downarrow \text { IL-6-induced p-STAT3 } \\
\text { - } \uparrow \text { Pax5 (first) and Bcl-6 mRNA } \\
\text { levels }\end{array}$ & $\begin{array}{l}\text { - Inhibited by the } \mathrm{CB}_{2} \text { agonist } \\
\text { HU308 } \\
\text { - Do not degrade } 1 \kappa B a \text { as the } \\
\text { NF- } \mathrm{kB} \text { inhibitor Bay11-7085 }\end{array}$ & $\begin{array}{l}\text { Feng et al. } \\
(2014)\end{array}$ \\
\hline \multicolumn{7}{|l|}{ Neutrophils } \\
\hline \multirow[t]{5}{*}{ Blood } & $2-A G$ & $1 \mu \mathrm{M}(4 \mathrm{~h})$ & 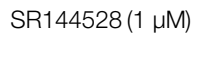 & $\begin{array}{l}\text { No effect on migration in } \\
\text { presence of NDGA }\end{array}$ & & $\begin{array}{l}\text { Oka et al. } \\
(2004)\end{array}$ \\
\hline & & 300 nM (20 min) & SR144528 (1 $\mu \mathrm{M})$ & $\begin{array}{l}\text { No motility or morphologic } \\
\text { alterations }\end{array}$ & & $\begin{array}{l}\text { Kurihara et al. } \\
(2006)\end{array}$ \\
\hline & JWH-015 & $\begin{array}{l}100 \mathrm{nM}-10 \mu \mathrm{M} \\
(20 \mathrm{~min})\end{array}$ & SR144528 (1 $\mu \mathrm{M})$ & $\begin{array}{l}\text { No motility or morphologic } \\
\text { alterations }\end{array}$ & & $\begin{array}{l}\text { Kurihara et al. } \\
(2006)\end{array}$ \\
\hline & $\mathrm{JWH}-133$ & $1 \mu \mathrm{M}(2 \mathrm{~h})$ & - & No effect on neutrophil function & & $\begin{array}{l}\text { Zhou et al. } \\
\text { (2020) }\end{array}$ \\
\hline & & 100 nM (5 h) & SR144528 (1 $\mu \mathrm{M})$ & $\begin{array}{l}\text { No effect on IL-8-induced } \\
\text { migration }\end{array}$ & (Continued on & $\begin{array}{l}\text { Frei et al. } \\
(2016) \\
\text { ollowing page) }\end{array}$ \\
\hline
\end{tabular}


TABLE 1 | (Continued) $\mathrm{CB}_{2}$-mediated effects on human leukocytes and related human cell lines.

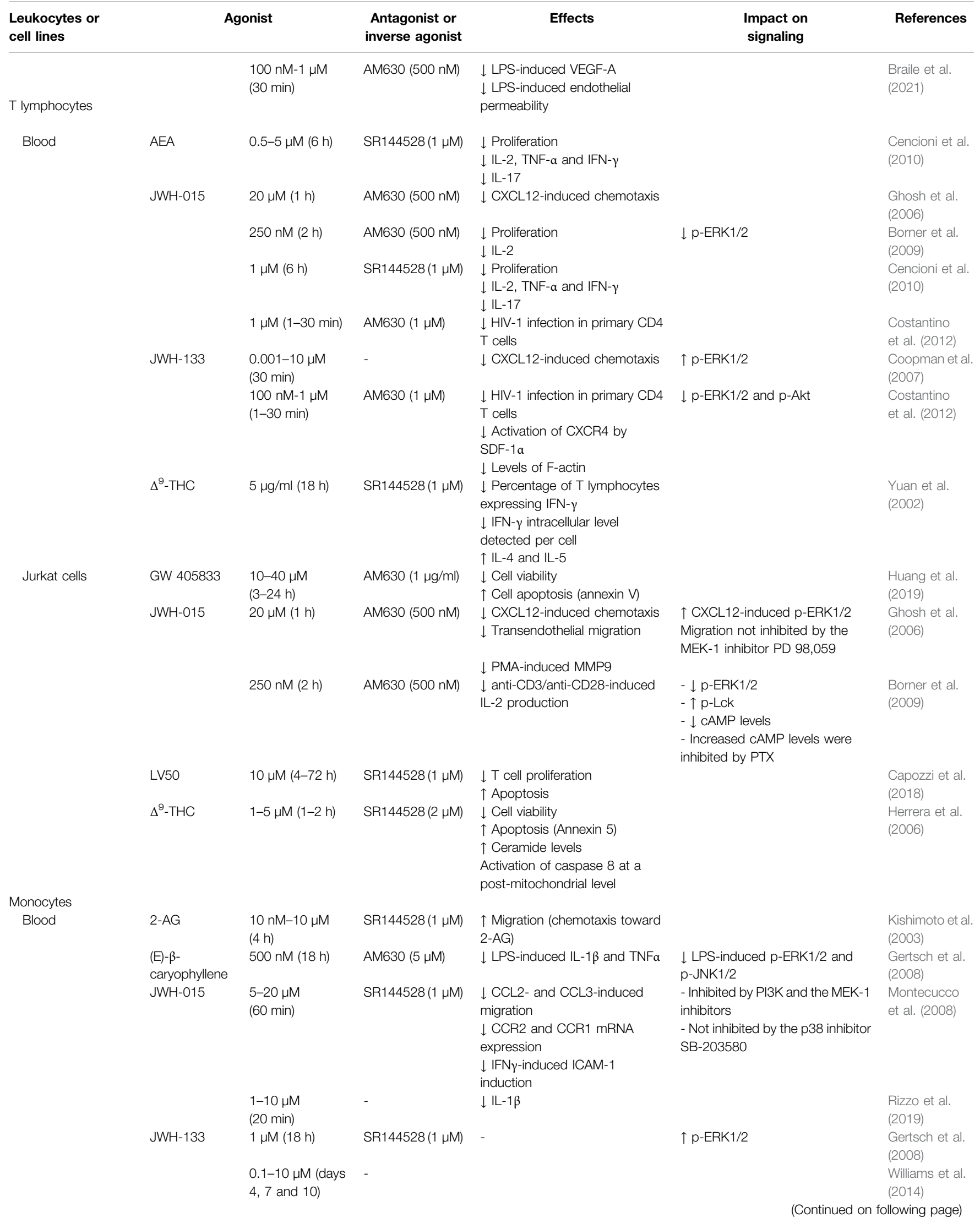


TABLE 1 | (Continued) $\mathrm{CB}_{2}$-mediated effects on human leukocytes and related human cell lines.

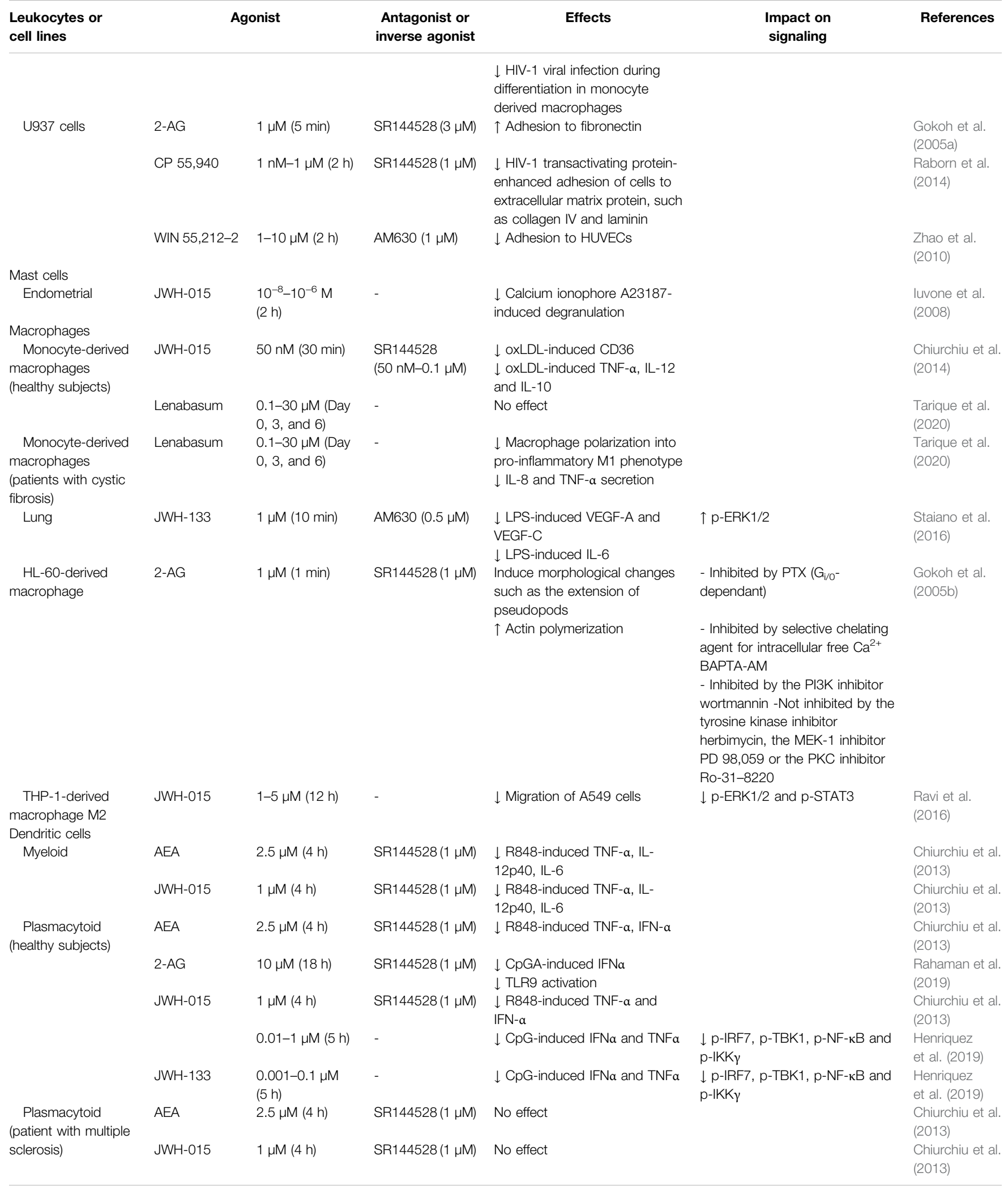


playing an important role in B lymphocyte repertoire formation (Pereira et al., 2009).

\section{Human Neutrophils}

Neutrophils are first responders of the innate immune system, playing crucial roles in acute inflammatory responses and host defense. They employ several strategies to fight microbes, including the phagocytosis and killing of pathogens with the help of their granule content. Studies showing a $\mathrm{CB}_{2}$-receptormediated effect of human neutrophils were not conclusive and contaminating eosinophils in neutrophil preparations might have caused a red herring situation, eosinophils being responsible for most of the $\mathrm{CB}_{2}$ receptor signal/effects (Figure 1 and Expression of the $C B_{1}$ and $C B_{2}$ Receptors by Human Blood Leukocytes). In fact, numerous studies indicated that endocannabinoids as well as selective and non-selective $\mathrm{CB}_{2}$ receptor agonists do not diminish human neutrophil functions (migration, superoxide generation and degranulation) via the $\mathrm{CB}_{2}$ receptor and when they display an inhibitory effect on their functional responses it is mostly related to a mechanism distinct from the $\mathrm{CB}_{1}$ and $\mathrm{CB}_{2}$ receptors (Deusch et al., 2003; Kraft et al., 2004; Oka et al., 2004; McHugh et al., 2008; Chouinard et al., 2011; Montecucco et al., 2012; Zhou et al., 2020), which is consistent with their lack/very low expression of the $\mathrm{CB}_{2}$ receptor. In contrast, JWH-133 inhibited the release of VEGF-A but not CXCL8 from LPS-stimulated human neutrophils, a phenomenon prevented by the $\mathrm{CB}_{2}$ receptor antagonist AM630 (Braile et al., 2021).

- In vivo studies indicated that mouse neutrophils are more responsive to $\mathrm{CB}_{2}$ receptor activation than human neutrophils. As such, $\mathrm{Cnr}^{-1-}$ mice models reported increased neutrophil numbers at inflammatory sites (Alferink et al., 2016; Kapellos et al., 2017; Kapellos et al., 2019). Accordingly, $\mathrm{CB}_{2}$ activation by selective agonists suppressed neutrophil recruitment to the inflammation site (Horvath et al., 2012; Andrade-Silva et al., 2016; Wang et al., 2016; Parlar et al., 2018; Kapellos et al., 2019). However, it is not clear whether the reported evidence is a matter of mouse neutrophil responsiveness or of indirect $\mathrm{CB}_{2}$-dependent effects mediated by other cells (Kraft and Kress 2005). At this point, we cannot exclude that a $\mathrm{CB}_{2}$-dependent mechanism prevents neutrophil recruitment into by impairing their transmigration into the tissues and by affecting other cells (e.g., endothelial cells) as proposed earlier (Nilsson et al., 2006).

\section{Human T Lymphocytes}

Cytotoxic CD8 T lymphocytes are responsible for the elimination of invading/dysfunctional cells while CD4 $\mathrm{T}$ lymphocytes produce a myriad of inflammatory mediators and are referred to as helper lymphocytes (Th). Although $\mathrm{CB}_{2}$ receptor expression was barely detected in circulating $\mathrm{T}$ lymphocytes (Figure 1), several studies reported that $\mathrm{CB}_{2}$ receptor expression is increased in activated $\mathrm{T}$ lymphocytes and that its activation decreases their proliferation (Borner et al., 2009; Cencioni et al., 2010; Capozzi et al., 2018). This is accompanied with decreased IL-2 production and increased apoptosis (Herrera et al., 2006; Borner et al., 2009;
Cencioni et al., 2010; Capozzi et al., 2018; Huang et al., 2019). Interestingly, $\mathrm{CB}_{2}$ receptor activation seems to exert divergent effects depending on the T lymphocyte subtype with the tendency to decrease human Th1 and Th17 functions, while promoting those of Th2. For instance, $\Delta^{9}$-THC decreased in a $\mathrm{CB}_{2}{ }^{-}$ dependant manner the percentage of human $\mathrm{T}$ lymphocytes expressing IFN- $\gamma$, and intracellular levels of IFN- $\gamma$ per cells (Th1), while increasing levels of IL-4 and IL-5 (Th2) (Yuan et al., 2002). Accordingly, a decrease in IL-17 levels was found in JWH-015-treated T lymphocytes (Cencioni et al., 2010). Finally, the $\mathrm{CB}_{2}$ agonist Lenabasum reduced TNF- $\alpha$ in both CD8 and CD4 $\mathrm{T}$ lymphocytes (Th1). The treatment also decreased IL-17 levels (Th17) as well as Th1 and Th17 respective signature transcription factors T-bet and ROR $\gamma \mathrm{t}$ (Tiberi et al., 2021).

\section{Human Monocytes}

Blood monocytes migrate into tissues where they differentiate into macrophages or convert into non-classical monocytes (Guilliams et al., 2018). 2-AG is a $\mathrm{CB}_{2}$-dependant human monocyte chemoattractant (Kishimoto et al., 2003) and induces the adhesion of human monocytic U937 cells to fibronectin (Gokoh et al., 2005a). However, JWH-015 decreased the CCL2-and CCL3induced migration of human monocytes by decreasing their receptors' expression (Montecucco et al., 2008). JWH-015 also reduces human monocyte differentiation and U937 cells adhesion to extracellular matrix proteins, both induced by HIV-1 (Raborn et al., 2014; Williams et al., 2014). Finally, $\mathrm{CB}_{2}$ receptor engagement in human monocytes was shown to decrease the LPS-induced IL$1 \beta$ and IL-6 production (Gu et al., 2019; Rizzo et al., 2019).

\section{Human Macrophages}

Macrophages are resident cells that are remarkably versatile, exerting important roles in development, homeostasis, tissue repair and immunity. The endocannabinoid 2-AG was found to induce shape changes of HL-60-derived macrophages in a $\mathrm{CB}_{2}-$ depandent manner (Gokoh et al., 2005b). Additionally, $\mathrm{CB}_{2}$ receptor activation with JWH-015 or JWH-133 decreased the LPS-induced VEGF-A, VEGF-C IL-6 release, as well as the oxLDL-induced release of TNF- $\alpha$, IL-12 and IL-10 (Chiurchiu et al., 2014; Staiano et al., 2016). In mice, the $\mathrm{CB}_{2}$ receptor was shown to switch the polarization of M1 macrophage into M2 macrophage (Duerr et al., 2014; Denaes et al., 2016; Du et al., 2018). Such a phenomenon has been partially observed in humans by Tarique et al. who showed that Lenabasum decreased the polarization (M1) of monocyte-derived macrophage obtained from cystic fibrosis patients (Tarique et al., 2020).

\section{Human Mast Cells}

Mast cells are strategically located at the interface with the external environment, acting as key initiators of local inflammatory responses (Elieh Ali Komi et al., 2020). The first evidence that they could be regulated by the $\mathrm{CB}_{2}$ receptor came from the rat basophilic leukemia cell line (RBL-2H3) expressing the $\mathrm{CB}_{2}$ receptor (Facci et al., 1995). However, while the authors showed that $N$-palmitoyl-ethanolamine (PEA) inhibited serotonin release AEA did not. However, PEA interacts with 
PPARa (Lo Verme et al., 2005) and its initial effects are likely linked to PPARa. In humans, the treatment of isolated mast cells with JWH-015 decreased their degranulation in vitro (Iuvone et al., 2008).

\section{Human Dendritic Cells}

Dendritic cells are sentinels of the immune system bridging the innate and adaptive immunity by ingesting pathogens and transporting antigens to lymphoid tissues. Stimulation of $\mathrm{CB}_{2}$ receptor with $\mathrm{CB}_{2}$ receptor agonists reduced their cytokine production. Indeed, AEA and JWH-015 decreased R848induced levels of TNF- $\alpha$, IL-12p40 and IL- 6 by myeloid dendritic cells while AEA, 2-AG, JWH-015 and JWH-133 decreased levels of R848-and/or CpG-induced IFN- $\alpha$ by plasmacytoid dendritic cells by a mechanisms involving NF- $\kappa \mathrm{B}$ and IKK $\gamma$ signalization (Chiurchiu et al., 2013; Henriquez et al., 2019; Rahaman et al., 2019).

\section{CONCLUSION}

It is becoming clear that the $\mathrm{CB}_{2}$ receptor plays important roles in the regulation of several inflammatory processes. However, while the first studies investigating the role of this receptor in mice led to the concept that its function was mainly anti-inflammatory, new evidence is challenging this concept, notably in allergic diseases, which usually involve cells such as eosinophils and B lymphocytes, whose functional responses to $\mathrm{CB}_{2}$ receptor activation simulates them, in human-based studies. Moreover, the scarcity of human studies investigating the $\mathrm{CB}_{2}$ receptor makes our understanding of the latter difficult at this point and underscores the urgency of performing additional work involving human samples/cells to deepen our understanding of $\mathrm{CB}_{2}$-receptor-driven inflammatory responses and establish to what extent we can translate findings from experimental models to the clinic. It is thus urgent to further characterize the functions of the $\mathrm{CB}_{2}$ receptor in human leukocytes and inflammatory diseases.

\section{REFERENCES}

Agudelo, M., Newton, C., Widen, R., Sherwood, T., Nong, L., Friedman, H., et al. (2008). Cannabinoid Receptor 2 (CB2) Mediates Immunoglobulin Class Switching from IgM to IgE in Cultures of Murine-Purified B Lymphocytes. J. Neuroimmune Pharmacol. 3 (1), 35-42. doi:10.1007/s11481-007-9088-9

Alferink, J., Specht, S., Arends, H., Schumak, B., Schmidt, K., Ruland, C., et al. (2016). Cannabinoid Receptor 2 Modulates Susceptibility to Experimental Cerebral Malaria through a CCL17-dependent Mechanism. J. Biol. Chem. 291 (37), 19517-19531. doi:10.1074/jbc.M116.746594

Andrade-Silva, M., Correa, L. B., Candéa, A. L., Cavalher-Machado, S. C., Barbosa, H. S., Rosas, E. C., et al. (2016). The Cannabinoid 2 Receptor Agonist $\beta$ caryophyllene Modulates the Inflammatory Reaction Induced by Mycobacterium Bovis BCG by Inhibiting Neutrophil Migration. Inflamm. Res. 65 (11), 869-879. doi:10.1007/s00011-016-0969-3

Basu, S., Ray, A., and Dittel, B. N. (2013). Cannabinoid Receptor 2 (CB2) Plays a Role in the Generation of Germinal Center and Memory B Cells, but Not in the Production of Antigen-Specific IgG and IgM, in Response to T-dependent Antigens. PLoS One 8 (6), e67587. doi:10.1371/journal.pone.0067587

\section{DATA AVAILABILITY STATEMENT}

The original contributions presented in the study are included in the article, further inquiries can be directed to the corresponding author.

\section{ETHICS STATEMENT}

The studies involving human participants were reviewed and approved by the Comité d'éthique de la recherche de l'Institut universitaire de cardiologie et de pneumologie de Québec. The participants provided their written informed consent to participate in this study.

\section{AUTHOR CONTRIBUTIONS}

Conceptualization: MS, VR, VD, and NF; Investigation: MS and VR; Data curation-formal analysis: MS, VR, and NF; Writing-original draft: MS and NF; Writing_review, editing, and revision: MS, VR, VD, and NF.

\section{FUNDING}

This work was supported by grants to NF from The Natural Sciences and Engineering Research Council of Canada (RGPIN2021-03777) and to VD from the Canada Excellence Research Chair on the Microbiome-Endocannabinoidome Axis in Metabolic Health. VR was supported by a post-doctoral award from the Québec Heart and Lung Institute Foundation.

\section{ACKNOWLEDGMENTS}

We would like to thank Andréanne Côté and Annie Roy for providing the blood samples.

Börner, C., Smida, M., Höllt, V., Schraven, B., and Kraus, J. (2009). Cannabinoid Receptor Type 1- and 2-mediated Increase in Cyclic AMP Inhibits T Cell Receptor-Triggered Signaling. J. Biol. Chem. 284 (51), 35450-35460. doi:10. 1074/jbc.M109.006338

Bozkurt, T. E., Kaya, Y., Durlu-Kandilci, N. T., Onder, S., and Sahin-Erdemli, I. (2016). The Effect of Cannabinoids on Dinitrofluorobenzene-Induced Experimental Asthma in Mice. Respir. Physiol. Neurobiol. 231, 7-13. doi:10. 1016/j.resp.2016.05.012

Braile, M., Cristinziano, L., Marcella, S., Varricchi, G., Marone, G., Modestino, L., et al. (2021). LPS-mediated Neutrophil VEGF-A Release Is Modulated by Cannabinoid Receptor Activation. J. Leukoc. Biol. 109 (3), 621-631. doi:10. 1002/JLB.3A0520-187R

Brown, S. M., Wager-Miller, J., and Mackie, K. (2002). Cloning and Molecular Characterization of the Rat CB2 Cannabinoid Receptor. Biochim. Biophys. Acta 1576 (3), 255-264. doi:10.1016/s0167-4781(02)00341-x

Cakir, M., Tekin, S., Doganyigit, Z., Cakan, P., and Kaymak, E. (2019). The Protective Effect of Cannabinoid Type 2 Receptor Activation on Renal Ischemia-Reperfusion Injury. Mol. Cel Biochem 462 (1-2), 123-132.

Capozzi, A., Mattei, V., Martellucci, S., Manganelli, V., Saccomanni, G., Garofalo, T., et al. (2018). Anti-proliferative Properties and Proapoptotic Function of 
New CB2 Selective Cannabinoid Receptor Agonist in Jurkat Leukemia Cells. Int. J. Mol. Sci. 19 (7), 1958. doi:10.3390/ijms19071958

Carayon, P., Marchand, J., Dussossoy, D., Derocq, J. M., Jbilo, O., Bord, A., et al. (1998). Modulation and Functional Involvement of CB2 Peripheral Cannabinoid Receptors during B-Cell Differentiation. Blood 92 (10), 3605-3615. doi:10.1182/blood.v92.10.3605.422k05_3605_3615

Castaneda, J. T., Harui, A., Kiertscher, S. M., Roth, J. D., and Roth, M. D. (2013). Differential Expression of Intracellular and Extracellular $\mathrm{CB}(2)$ Cannabinoid Receptor Protein by Human Peripheral Blood Leukocytes. J. Neuroimmune Pharmacol. 8 (1), 323-332. doi:10.1007/s11481-012-9430-8

Cencioni, M. T., Chiurchiù, V., Catanzaro, G., Borsellino, G., Bernardi, G., Battistini, L., et al. (2010). Anandamide Suppresses Proliferation and Cytokine Release from Primary Human T-Lymphocytes Mainly via CB2 Receptors. PLoS One 5 (1), e8688. doi:10.1371/journal.pone.0008688

Chiurchiù, V., Cencioni, M. T., Bisicchia, E., De Bardi, M., Gasperini, C., Borsellino, G., et al. (2013). Distinct Modulation of Human Myeloid and Plasmacytoid Dendritic Cells by Anandamide in Multiple Sclerosis. Ann. Neurol. 73 (5), 626-636. doi:10.1002/ana.23875

Chiurchiù, V., Lanuti, M., Catanzaro, G., Fezza, F., Rapino, C., and Maccarrone, M. (2014). Detailed Characterization of the Endocannabinoid System in Human Macrophages and Foam Cells, and Anti-inflammatory Role of Type-2 Cannabinoid Receptor. Atherosclerosis 233 (1), 55-63. doi:10.1016/j. atherosclerosis.2013.12.042

Chouinard, F., Lefebvre, J. S., Navarro, P., Bouchard, L., Ferland, C., LalancetteHébert, M., et al. (2011). The Endocannabinoid 2-Arachidonoyl-Glycerol Activates Human Neutrophils: Critical Role of its Hydrolysis and de novo Leukotriene B4 Biosynthesis. J. Immunol. 186 (5), 3188-3196. doi:10.4049/ jimmunol.1002853

Chouinard, F., Turcotte, C., Guan, X., Larose, M. C., Poirier, S., Bouchard, L., et al. (2013). 2-Arachidonoyl-glycerol- and Arachidonic Acid-Stimulated Neutrophils Release Antimicrobial Effectors against E. coli, S. aureus, HSV1, and RSV. J. Leukoc. Biol. 93 (2), 267-276. doi:10.1189/jlb.0412200

Coopman, K., Smith, L. D., Wright, K. L., and Ward, S. G. (2007). Temporal Variation in CB2R Levels Following T Lymphocyte Activation: Evidence that Cannabinoids Modulate CXCL12-Induced Chemotaxis. Int. Immunopharmacol 7 (3), 360-371. doi:10.1016/j.intimp.2006.11.008

Corrado, A., Battle, M., Wise, S. K., Lee, F. E., Guidot, D. M., DelGaudio, J. M., et al. (2018). Endocannabinoid Receptor CB2R Is Significantly Expressed in AspirinExacerbated Respiratory Disease: a Pilot Study. Int. Forum Allergy Rhinol 8 (10), 1184-1189. doi:10.1002/alr.22163

Costantino, C. M., Gupta, A., Yewdall, A. W., Dale, B. M., Devi, L. A., and Chen, B. K. (2012). Cannabinoid Receptor 2-mediated Attenuation of CXCR4-Tropic HIV Infection in Primary CD4+ T Cells. PLoS One 7 (3), e33961. doi:10.1371/ journal.pone.0033961

Denaës, T., Lodder, J., Chobert, M. N., Ruiz, I., Pawlotsky, J. M., Lotersztajn, S., et al. (2016). The Cannabinoid Receptor 2 Protects against Alcoholic Liver Disease via a Macrophage Autophagy-dependent Pathway. Sci. Rep. 6, 28806. doi:10.1038/srep28806

Deusch, E., Kraft, B., Nahlik, G., Weigl, L., Hohenegger, M., and Kress, H. G. (2003). No Evidence for Direct Modulatory Effects of delta 9tetrahydrocannabinol on Human Polymorphonuclear Leukocytes. J. Neuroimmunol 141 (1-2), 99-103. doi:10.1016/s0165-5728(03)00259-5

Devane, W. A., Dysarz, F. A., 3rd, Johnson, M. R., Melvin, L. S., and Howlett, A. C. (1988). Determination and Characterization of a Cannabinoid Receptor in Rat Brain. Mol. Pharmacol. 34 (5), 605-613.

Di Marzo, V., Melck, D., Bisogno, T., and De Petrocellis, L. (1998). Endocannabinoids: Endogenous Cannabinoid Receptor Ligands with Neuromodulatory Action. Trends Neurosci. 21 (12), 521-528. doi:10.1016/s0166-2236(98)01283-1

Di Marzo, V. (2018). New Approaches and Challenges to Targeting the Endocannabinoid System. Nat. Rev. Drug Discov. 17 (9), 623-639. doi:10. 1038/nrd.2018.115

Do, Y., McKallip, R. J., Nagarkatti, M., and Nagarkatti, P. S. (2004). Activation through Cannabinoid Receptors 1 and 2 on Dendritic Cells Triggers NFkappaB-dependent Apoptosis: Novel Role for Endogenous and Exogenous Cannabinoids in Immunoregulation. J. Immunol. 173 (4), 2373-2382. doi:10.4049/jimmunol.173.4.2373

Dothel, G., Chang, L., Shih, W., Barbaro, M. R., Cremon, C., Stanghellini, V., et al. (2019). Micro-Opioid Receptor, Beta-Endorphin, and Cannabinoid Receptor-2
Are Increased in the Colonic Mucosa of Irritable Bowel Syndrome Patients. Neurogastroenterol Motil. 31 (11), e13688. doi:10.1111/nmo.13688

Du, Y., Ren, P., Wang, Q., Jiang, S. K., Zhang, M., Li, J. Y., et al. (2018). Cannabinoid 2 Receptor Attenuates Inflammation during Skin Wound Healing by Inhibiting M1 Macrophages rather Than Activating M2 Macrophages. J. Inflamm. (Lond) 15, 25. doi:10.1186/s12950-018-0201-z

Duerr, G. D., Heinemann, J. C., Suchan, G., Kolobara, E., Wenzel, D., Geisen, C., et al. (2014). The Endocannabinoid-CB2 Receptor axis Protects the Ischemic Heart at the Early Stage of Cardiomyopathy. Basic Res. Cardiol. 109 (4), 425. doi:10.1007/s00395-014-0425-x

Elieh Ali Komi, D., Wöhrl, S. L., and Bielory, L. (2020). Mast Cell Biology at Molecular Level: a Comprehensive Review. Clin. Rev. Allergy Immunol. 58 (3), 342-365. doi:10.1007/s12016-019-08769-2

Ellert-Miklaszewska, A., Grajkowska, W., Gabrusiewicz, K., Kaminska, B., and Konarska, L. (2007). Distinctive Pattern of Cannabinoid Receptor Type II (CB2) Expression in Adult and Pediatric Brain Tumors. Brain Res. 1137 (1), 161-169. doi:10.1016/j.brainres.2006.12.060

Facci, L., Dal Toso, R., Romanello, S., Buriani, A., Skaper, S. D., and Leon, A. (1995). Mast Cells Express a Peripheral Cannabinoid Receptor with Differential Sensitivity to Anandamide and Palmitoylethanolamide. Proc. Natl. Acad. Sci. U S A. 92 (8), 3376-3380. doi:10.1073/pnas.92.8.3376

Fantauzzi, M. F., Aguiar, J. A., Tremblay, B. J., Mansfield, M. J., Yanagihara, T., Chandiramohan, A., et al. (2020). Expression of Endocannabinoid System Components in Human Airway Epithelial Cells: Impact of Sex and Chronic Respiratory Disease Status. ERJ Open Res. 6 (4). doi:10.1183/23120541.001282020

Feng, R., Milcarek, C. A., and Xie, X. Q. (2014). Antagonism of Cannabinoid Receptor 2 Pathway Suppresses IL-6-induced Immunoglobulin IgM Secretion. BMC Pharmacol. Toxicol. 15, 30. doi:10.1186/2050-6511-15-30

Ferrini, M. E., Hong, S., Stierle, A., Stierle, D., Stella, N., Roberts, K., et al. (2017). CB2 Receptors Regulate Natural Killer Cells that Limit Allergic Airway Inflammation in a Murine Model of Asthma. Allergy 72 (6), 937-947. doi:10.1111/all.13107

Frei, R. B., Luschnig, P., Parzmair, G. P., Peinhaupt, M., Schranz, S., Fauland, A., et al. (2016). Cannabinoid Receptor 2 Augments Eosinophil Responsiveness and Aggravates Allergen-Induced Pulmonary Inflammation in Mice. Allergy 71 (7), 944-956. doi:10.1111/all.12858

Freundt-Revilla, J., Heinrich, F., Zoerner, A., Gesell, F., Beyerbach, M., Shamir, M., et al. (2018). The Endocannabinoid System in Canine Steroid-Responsive Meningitis-Arteritis and Intraspinal Spirocercosis. PLoS One 13 (2), e0187197. doi:10.1371/journal.pone.0187197

Fukuda, H., Abe, T., and Yoshihara, S. (2010). The Cannabinoid Receptor Agonist WIN 55,212-2 Inhibits Antigen-Induced Plasma Extravasation in guinea Pig Airways. Int. Arch. Allergy Immunol. 152 (3), 295-300. doi:10.1159/000283042

Galiègue, S., Mary, S., Marchand, J., Dussossoy, D., Carrière, D., Carayon, P., et al. (1995). Expression of central and Peripheral Cannabinoid Receptors in Human Immune Tissues and Leukocyte Subpopulations. Eur. J. Biochem. 232 (1), 54-61. doi:10.1111/j.1432-1033.1995.tb20780.x

Gertsch, J., Leonti, M., Raduner, S., Racz, I., Chen, J. Z., Xie, X. Q., et al. (2008). Beta-caryophyllene Is a Dietary Cannabinoid. Proc. Natl. Acad. Sci. U S A. 105 (26), 9099-9104. doi:10.1073/pnas.0803601105

Ghosh, S., Preet, A., Groopman, J. E., and Ganju, R. K. (2006). Cannabinoid Receptor CB2 Modulates the CXCL12/CXCR4-Mediated Chemotaxis of T Lymphocytes. Mol. Immunol. 43 (14), 2169-2179. doi:10.1016/j.molimm.2006.01.005

Gokoh, M., Kishimoto, S., Oka, S., Metani, Y., and Sugiura, T. (2005a). 2Arachidonoylglycerol, an Endogenous Cannabinoid Receptor Ligand, Enhances the Adhesion of HL-60 Cells Differentiated into Macrophage-like Cells and Human Peripheral Blood Monocytes. FEBS Lett. 579 (28), 6473-6478. doi:10.1016/j.febslet.2005.10.030

Gokoh, M., Kishimoto, S., Oka, S., Mori, M., Waku, K., Ishima, Y., et al. (2005b). 2arachidonoylglycerol, an Endogenous Cannabinoid Receptor Ligand, Induces Rapid Actin Polymerization in HL-60 Cells Differentiated into Macrophagelike Cells. Biochem. J. 386 (Pt 3), 583-589. doi:10.1042/BJ20041163

Graham, E. S., Angel, C. E., Schwarcz, L. E., Dunbar, P. R., and Glass, M. (2010). Detailed Characterisation of CB2 Receptor Protein Expression in Peripheral Blood Immune Cells from Healthy Human Volunteers Using Flow Cytometry. Int. J. Immunopathol Pharmacol. 23 (1), 25-34. doi:10.1177/ 039463201002300103 
Greco, R., Demartini, C., Zanaboni, A., Tumelero, E., Elisa, C., Persico, A., et al. (2021). Characterization of CB2 Receptor Expression in Peripheral Blood Monocytes of Acute Ischemic Stroke Patients. Transl Stroke Res. 12 (4), 550-558. doi:10.1007/s12975-020-00851-8

Gu, Z., Singh, S., Niyogi, R. G., Lamont, G. J., Wang, H., Lamont, R. J., et al. (2019). Marijuana-Derived Cannabinoids Trigger a CB2/PI3K Axis of Suppression of the Innate Response to Oral Pathogens. Front. Immunol. 10, 2288. doi:10.3389/ fimmu.2019.02288

Guilliams, M., Mildner, A., and Yona, S. (2018). Developmental and Functional Heterogeneity of Monocytes. Immunity 49 (4), 595-613. doi:10.1016/j.immuni. 2018.10.005

Gustafsson, K., Christensson, B., Sander, B., and Flygare, J. (2006). Cannabinoid Receptor-Mediated Apoptosis Induced by $\mathrm{R}(+)$-methanandamide and Win55,212-2 Is Associated with Ceramide Accumulation and P38 Activation in Mantle Cell Lymphoma. Mol. Pharmacol. 70 (5), 1612-1620. doi:10.1124/mol.106.025981

Haruna, T., Soga, M., Morioka, Y., Imura, K., Furue, Y., Yamamoto, M., et al. (2017). The Inhibitory Effect of S-777469, a Cannabinoid Type 2 Receptor Agonist, on Skin Inflammation in Mice. Pharmacology 99 (5-6), 259-267. doi:10.1159/000455916

Henriquez, J. E., Crawford, R. B., and Kaminski, N. E. (2019). Suppression of CpGODN-Mediated IFN $\alpha$ and TNF $\alpha$ Response in Human Plasmacytoid Dendritic Cells (pDC) by Cannabinoid Receptor 2 (CB2)-specific Agonists. Toxicol. Appl. Pharmacol. 369, 82-89. doi:10.1016/j.taap.2019.02.013

Herrera, B., Carracedo, A., Diez-Zaera, M., Gómez del Pulgar, T., Guzmán, M. G., and Velasco, G. (2006). The CB2 Cannabinoid Receptor Signals Apoptosis via Ceramide-dependent Activation of the Mitochondrial Intrinsic Pathway. Exp. Cel Res 312 (11), 2121-2131. doi:10.1016/j.yexcr.2006.03.009

Horváth, B., Magid, L., Mukhopadhyay, P., Bátkai, S., Rajesh, M., Park, O., et al. (2012). A New Cannabinoid CB2 Receptor Agonist HU-910 Attenuates Oxidative Stress, Inflammation and Cell Death Associated with Hepatic Ischaemia/reperfusion Injury. Br. J. Pharmacol. 165 (8), 2462-2478. doi:10. 1111/j.1476-5381.2011.01381.x

Howlett, A. C., and Abood, M. E. (2017). CB1 and CB2 Receptor Pharmacology. Adv. Pharmacol. 80, 169-206. doi:10.1016/bs.apha.2017.03.007

Huang, Z. B., Zheng, Y. X., Li, N., Cai, S. L., Huang, Y., Wang, J., et al. (2019). Protective Effects of Specific Cannabinoid Receptor 2 Agonist GW405833 on Concanavalin A-Induced Acute Liver Injury in Mice. Acta Pharmacol. Sin 40 (11), 1404-1411. doi:10.1038/s41401-019-0213-0

Hurrell, B. P., Helou, D. G., Shafiei-Jahani, P., Howard, E., Painter, J. D., Quach, C., et al. (2021). Cannabinoid Receptor II Engagement Promotes ILC2 Expansion and Enhances ILC2-dependent Airway Hyperreactivity. J. Allergy Clin. Immunol.

Iuvone, T., De Filippis, D., Di Spiezio Sardo, A., D’Amico, A., Simonetti, S., Sparice, S., et al. (2008). Selective CB2 Up-Regulation in Women Affected by Endometrial Inflammation. J. Cel Mol Med 12 (2), 661-670. doi:10.1111/j. 1582-4934.2007.00085.x

Jordà, M. A., Verbakel, S. E., Valk, P. J., Vankan-Berkhoudt, Y. V., Maccarrone, M., Finazzi-Agrò, A., et al. (2002). Hematopoietic Cells Expressing the Peripheral Cannabinoid Receptor Migrate in Response to the Endocannabinoid 2arachidonoylglycerol. Blood 99 (8), 2786-2793. doi:10.1182/blood.v99.8.2786

Kapellos, T. S., Recio, C., Greaves, D. R., and Iqbal, A. J. (20172017). Cannabinoid Receptor 2 Modulates Neutrophil Recruitment in a Murine Model of Endotoxemia. Mediators Inflamm. 2017, 4315412. doi:10.1155/2017/4315412

Kapellos, T. S., Taylor, L., Feuerborn, A., Valaris, S., Hussain, M. T., Rainger, G. E., et al. (2019). Cannabinoid Receptor 2 Deficiency Exacerbates Inflammation and Neutrophil Recruitment. FASEB J. 33 (5), 6154-6167. doi:10.1096/fj. 201802524R

Kishimoto, S., Gokoh, M., Oka, S., Muramatsu, M., Kajiwara, T., Waku, K., et al. (2003). 2-arachidonoylglycerol Induces the Migration of HL-60 Cells Differentiated into Macrophage-like Cells and Human Peripheral Blood Monocytes through the Cannabinoid CB2 Receptor-dependent Mechanism. J. Biol. Chem. 278 (27), 24469-24475. doi:10.1074/jbc.M301359200

Kishimoto, S., Oka, S., Gokoh, M., and Sugiura, T. (2006). Chemotaxis of Human Peripheral Blood Eosinophils to 2-arachidonoylglycerol: Comparison with Other Eosinophil Chemoattractants. Int. Arch. Allergy Immunol. $140 \mathrm{Suppl}$ 1 (Suppl. 1), 3-7. doi:10.1159/000092704
Kraft, B., and Kress, H. G. (2005). Indirect CB2 Receptor and Mediator-dependent Stimulation of Human Whole-Blood Neutrophils by Exogenous and Endogenous Cannabinoids. J. Pharmacol. Exp. Ther. 315 (2), 641-647. doi:10.1124/jpet.105.084269

Kraft, B., Wintersberger, W., and Kress, H. G. (2004). Cannabinoid Receptorindependent Suppression of the Superoxide Generation of Human Neutrophils (PMN) by CP55 940, but Not by Anandamide. Life Sci. 75 (8), 969-977. doi:10. 1016/j.lfs.2004.02.007

Kurihara, R., Tohyama, Y., Matsusaka, S., Naruse, H., Kinoshita, E., Tsujioka, T., et al. (2006). Effects of Peripheral Cannabinoid Receptor Ligands on Motility and Polarization in Neutrophil-like HL60 Cells and Human Neutrophils. J. Biol. Chem. 281 (18), 12908-12918. doi:10.1074/jbc.M510871200

Larose, M. C., Archambault, A. S., Provost, V., Laviolette, M., and Flamand, N. (2017). Regulation of Eosinophil and Group 2 Innate Lymphoid Cell Trafficking in Asthma. Front. Med. (Lausanne) 4, 136. doi:10.3389/fmed. 2017.00136

Larose, M. C., Turcotte, C., Chouinard, F., Ferland, C., Martin, C., Provost, V., et al. (2014). Mechanisms of Human Eosinophil Migration Induced by the Combination of IL-5 and the Endocannabinoid 2-Arachidonoyl-Glycerol. J. Allergy Clin. Immunol. 133 (5), 1480-1483. doi:10.1016/j.jaci.2013.12.1081

Lee, S. F., Newton, C., Widen, R., Friedman, H., and Klein, T. W. (2001). Downregulation of Cannabinoid Receptor 2 (CB2) Messenger RNA Expression during In Vitro Stimulation of Murine Splenocytes with Lipopolysaccharide. Adv. Exp. Med. Biol. 493, 223-228. doi:10.1007/0-30647611-8_26

Liebling, P. D., and Siu, S. (2013). A Novel Cause of Eosinophilic Pneumonia: Recreational Marijuana Exposure. J. Bronchology Interv. Pulmonol 20 (2), 183-185. doi:10.1097/LBR.0b013e31828caa0d

Lo Verme, J., Fu, J., Astarita, G., La Rana, G., Russo, R., Calignano, A., et al. (2005). The Nuclear Receptor Peroxisome Proliferator-Activated Receptor-Alpha Mediates the Anti-inflammatory Actions of Palmitoylethanolamide. Mol. Pharmacol. 67 (1), 15-19. doi:10.1124/mol.104.006353

Matsuda, L. A., Lolait, S. J., Brownstein, M. J., Young, A. C., and Bonner, T. I. (1990). Structure of a Cannabinoid Receptor and Functional Expression of the Cloned cDNA. Nature 346 (6284), 561-564. doi:10.1038/346561a0

McHugh, D., Tanner, C., Mechoulam, R., Pertwee, R. G., and Ross, R. A. (2008). Inhibition of Human Neutrophil Chemotaxis by Endogenous Cannabinoids and Phytocannabinoids: Evidence for a Site Distinct from CB1 and CB2. Mol. Pharmacol. 73 (2), 441-450. doi:10.1124/mol.107.041863

Montecucco, F., Burger, F., Mach, F., and Steffens, S. (2008). CB2 Cannabinoid Receptor Agonist JWH-015 Modulates Human Monocyte Migration through Defined Intracellular Signaling Pathways. Am. J. Physiol. Heart Circ. Physiol. 294 (3), H1145-H1155. doi:10.1152/ajpheart.01328.2007

Montecucco, F., Di Marzo, V., da Silva, R. F., Vuilleumier, N., Capettini, L., Lenglet, S., et al. (2012). The Activation of the Cannabinoid Receptor Type 2 Reduces Neutrophilic Protease-Mediated Vulnerability in Atherosclerotic Plaques. Eur. Heart J. 33 (7), 846-856. doi:10.1093/eurheartj/ehr449

Mull, E. S., Erdem, G., Nicol, K., Adler, B., and Shell, R. (2020). Eosinophilic Pneumonia and Lymphadenopathy Associated with Vaping and Tetrahydrocannabinol Use. Pediatrics 145 (4). doi:10.1542/peds.2019-3007

Munro, S., Thomas, K. L., and Abu-Shaar, M. (1993). Molecular Characterization of a Peripheral Receptor for Cannabinoids. Nature 365 (6441), 61-65. doi:10. 1038/365061a0

Natarajan, A., Shah, P., Mirrakhimov, A. E., and Hussain, N. (20132013). Eosinophilic Pneumonia Associated with Concomitant Cigarette and Marijuana Smoking. BMJ Case Rep.. doi:10.1136/bcr-2013-009001

Nilsson, O., Fowler, C. J., and Jacobsson, S. O. (2006). The Cannabinoid Agonist WIN 55,212-2 Inhibits TNF-Alpha-Induced Neutrophil Transmigration across ECV304 Cells. Eur. J. Pharmacol. 547 (1-3), 165-173. doi:10.1016/j.ejphar.2006. 07.016

Öcal, N., Doğan, D., Çiçek, A. F., Yücel, O. E., and Tozkoparan, E. (2016). Acute Eosinophilic Pneumonia with Respiratory Failure Induced by Synthetic Cannabinoid Inhalation. Balkan Med. J. 33 (6), 688-690. doi:10.5152/ balkanmedj.2016.151145

Oka, S., Ikeda, S., Kishimoto, S., Gokoh, M., Yanagimoto, S., Waku, K., et al. (2004). 2-arachidonoylglycerol, an Endogenous Cannabinoid Receptor Ligand, Induces the Migration of EoL-1 Human Eosinophilic Leukemia Cells and Human 
Peripheral Blood Eosinophils. J. Leukoc. Biol. 76 (5), 1002-1009. doi:10.1189/ jlb.0404252

Parlar, A., Arslan, S. O., Doğan, M. F., Çam, S. A., Yalçin, A., Elibol, E., et al. (2018). The Exogenous Administration of CB2 Specific Agonist, GW405833, Inhibits Inflammation by Reducing Cytokine Production and Oxidative Stress. Exp. Ther. Med. 16 (6), 4900-4908. doi:10.3892/etm.2018.6753

Pereira, J. P., An, J., Xu, Y., Huang, Y., and Cyster, J. G. (2009). Cannabinoid Receptor 2 Mediates the Retention of Immature B Cells in Bone Marrow Sinusoids. Nat. Immunol. 10 (4), 403-411. doi:10.1038/ni.1710

Raborn, E. S., Jamerson, M., Marciano-Cabral, F., and Cabral, G. A. (2014). Cannabinoid Inhibits HIV-1 Tat-Stimulated Adhesion of Human Monocyte-like Cells to Extracellular Matrix Proteins. Life Sci. 104 (1-2), 15-23. doi:10.1016/j.lfs.2014.04.008

Rahaman, O., Bhattacharya, R., Liu, C. S. C., Raychaudhuri, D., Ghosh, A. R., Bandopadhyay, P., et al. (2019). Cutting Edge: Dysregulated EndocannabinoidRheostat for Plasmacytoid Dendritic Cell Activation in a Systemic Lupus Endophenotype. J. Immunol. 202 (6), 1674-1679. doi:10.4049/jimmunol. 1801521

Ravi, J., Elbaz, M., Wani, N. A., Nasser, M. W., and Ganju, R. K. (2016). Cannabinoid Receptor-2 Agonist Inhibits Macrophage Induced EMT in Non-small Cell Lung Cancer by Downregulation of EGFR Pathway. Mol. Carcinog 55 (12), 2063-2076. doi:10.1002/mc.22451

Rayman, N., Lam, K. H., Laman, J. D., Simons, P. J., Löwenberg, B., Sonneveld, P., et al. (2004). Distinct Expression Profiles of the Peripheral Cannabinoid Receptor in Lymphoid Tissues Depending on Receptor Activation Status. J. Immunol. 172 (4), 2111-2117. doi:10.4049/jimmunol.172.4.2111

Rayman, N., Lam, K. H., Van Leeuwen, J., Mulder, A. H., Budel, L. M., Löwenberg, B., et al. (2007). The Expression of the Peripheral Cannabinoid Receptor on Cells of the Immune System and Non-Hodgkin's Lymphomas. Leuk. Lymphoma 48 (7), 1389-1399. doi:10.1080/10428190701377030

Rizzo, M. D., Crawford, R. B., Bach, A., Sermet, S., Amalfitano, A., and Kaminski, N. E. (2019). $\Delta$ 9-Tetrahydrocannabinol Suppresses Monocyte-Mediated Astrocyte Production of Monocyte Chemoattractant Protein 1 and Interleukin-6 in a Toll-Like Receptor 7-Stimulated Human Coculture. J. Pharmacol. Exp. Ther. 371 (1), 191-201. doi:10.1124/jpet.119.260661

Robinson, R. H., Meissler, J. J., Breslow-Deckman, J. M., Gaughan, J., Adler, M. W., and Eisenstein, T. K. (2013). Cannabinoids Inhibit T-Cells via Cannabinoid Receptor 2 in an In Vitro Assay for Graft Rejection, the Mixed Lymphocyte Reaction. J. Neuroimmune Pharmacol. 8 (5), 1239-1250. doi:10.1007/s11481013-9485-1

Sánchez, C., de Ceballos, M. L., Gomez del Pulgar, T., Rueda, D., Corbacho, C., Velasco, G., et al. (2001). Inhibition of Glioma Growth In Vivo by Selective Activation of the CB(2) Cannabinoid Receptor. Cancer Res. 61 (15), 5784-5789.

Sánchez López, A. J., Román-Vega, L., Ramil Tojeiro, E., Giuffrida, A., and GarcíaMerino, A. (2015). Regulation of Cannabinoid Receptor Gene Expression and Endocannabinoid Levels in Lymphocyte Subsets by Interferon- $\beta$ : a Longitudinal Study in Multiple Sclerosis Patients. Clin. Exp. Immunol. 179 (1), 119-127. doi:10.1111/cei.12443

Sauvaget, E., Dellamonica, J., Arlaud, K., Sanfiorenzo, C., Bernardin, G., Padovani, B., et al. (2010). Idiopathic Acute Eosinophilic Pneumonia Requiring ECMO in a Teenager Smoking Tobacco and Cannabis. Pediatr. Pulmonol 45 (12), 1246-1249. doi:10.1002/ppul.21314

Soethoudt, M., Grether, U., Fingerle, J., Grim, T. W., Fezza, F., de Petrocellis, L., et al. (2017). Cannabinoid CB2 Receptor Ligand Profiling Reveals Biased Signalling and Off-Target Activity. Nat. Commun. 8, 13958. doi:10.1038/ ncomms 13958

Staiano, R. I., Loffredo, S., Borriello, F., Iannotti, F. A., Piscitelli, F., Orlando, P., et al. (2016). Human Lung-Resident Macrophages Express CB1 and CB2 Receptors Whose Activation Inhibits the Release of Angiogenic and Lymphangiogenic Factors. J. Leukoc. Biol. 99 (4), 531-540. doi:10.1189/jlb. 3HI1214-584R

Tanikawa, T., Kurohane, K., and Imai, Y. (2007). Induction of Preferential Chemotaxis of Unstimulated B-Lymphocytes by 2-arachidonoylglycerol in
Immunized Mice. Microbiol. Immunol. 51 (10), 1013-1019. doi:10.1111/j. 1348-0421.2007.tb03985.x

Tarique, A. A., Evron, T., Zhang, G., Tepper, M. A., Morshed, M. M., Andersen, I. S. G., et al. (2020). Anti-inflammatory Effects of Lenabasum, a Cannabinoid Receptor Type 2 Agonist, on Macrophages from Cystic Fibrosis. J. Cyst Fibros 19 (5), 823-829. doi:10.1016/j.jcf.2020.03.015

Tiberi, M., Evron, T., Saracini, S., Boffa, L., Mercuri, N. B., Chintalacharuvu, S. R., et al. (2021). Potent T Cell-Mediated Anti-inflammatory Role of the Selective CB2 Agonist Lenabasum in Multiple Sclerosis. Neuropathol. Appl. Neurobiol..

Turcotte, C., Blanchet, M. R., Laviolette, M., and Flamand, N. (2016). The CB2 Receptor and its Role as a Regulator of Inflammation. Cell Mol Life Sci 73 (23), 4449-4470. doi:10.1007/s00018-016-2300-4

Turcotte, C., Chouinard, F., Lefebvre, J. S., and Flamand, N. (2015). Regulation of Inflammation by Cannabinoids, the Endocannabinoids 2-ArachidonoylGlycerol and Arachidonoyl-Ethanolamide, and Their Metabolites. J. Leukoc. Biol. 97 (6), 1049-1070. doi:10.1189/jlb.3RU0115-021R

Van Sickle, M. D., Duncan, M., Kingsley, P. J., Mouihate, A., Urbani, P., Mackie, K., et al. (2005). Identification and Functional Characterization of Brainstem Cannabinoid CB2 Receptors. Science 310 (5746), 329-332. doi:10.1126/ science. 1115740

Wang, L. L., Zhao, R., Li, J. Y., Li, S. S., Liu, M., Wang, M., et al. (2016). Pharmacological Activation of Cannabinoid 2 Receptor Attenuates Inflammation, Fibrogenesis, and Promotes Re-epithelialization during Skin Wound Healing. Eur. J. Pharmacol. 786, 128-136. doi:10.1016/j.ejphar.2016. 06.006

Williams, J. C., Appelberg, S., Goldberger, B. A., Klein, T. W., Sleasman, J. W., and Goodenow, M. M. (2014). $\Delta(9)$-Tetrahydrocannabinol Treatment during Human Monocyte Differentiation Reduces Macrophage Susceptibility to HIV-1 Infection. J. Neuroimmune Pharmacol. 9 (3), 369-379. doi:10.1007/ s11481-014-9527-3

Yuan, M., Kiertscher, S. M., Cheng, Q., Zoumalan, R., Tashkin, D. P., and Roth, M. D. (2002). Delta 9-Tetrahydrocannabinol Regulates Th1/Th2 Cytokine Balance in Activated Human T Cells. J. Neuroimmunol 133 (1-2), 124-131. doi:10.1016/ s0165-5728(02)00370-3

Zhao, Y., Yuan, Z., Liu, Y., Xue, J., Tian, Y., Liu, W., et al. (2010). Activation of Cannabinoid CB2 Receptor Ameliorates Atherosclerosis Associated with Suppression of Adhesion Molecules. J. Cardiovasc. Pharmacol. 55 (3), 292-298. doi:10.1097/FJC.0b013e3181d2644d

Zhou, L., Zhou, S., Yang, P., Tian, Y., Feng, Z., Xie, X. Q., et al. (2018). Targeted Inhibition of the Type 2 Cannabinoid Receptor Is a Novel Approach to Reduce Renal Fibrosis. Kidney Int. 94 (4), 756-772. doi:10.1016/j.kint.2018.05.023

Zhou, X., Yang, L., Fan, X., Zhao, X., Chang, N., Yang, L., et al. (2020). Neutrophil Chemotaxis and NETosis in Murine Chronic Liver Injury via Cannabinoid Receptor 1/Gai/o/ROS/P38 MAPK Signaling Pathway. Cells 9 (2). doi:10.3390/ cells 9020373

Conflict of Interest: The authors declare that the research was conducted in the absence of any commercial or financial relationships that could be construed as a potential conflict of interest.

Publisher's Note: All claims expressed in this article are solely those of the authors and do not necessarily represent those of their affiliated organizations, or those of the publisher, the editors and the reviewers. Any product that may be evaluated in this article, or claim that may be made by its manufacturer, is not guaranteed or endorsed by the publisher.

Copyright $\odot 2022$ Simard, Rakotoarivelo, Di Marzo and Flamand. This is an openaccess article distributed under the terms of the Creative Commons Attribution License (CC BY). The use, distribution or reproduction in other forums is permitted, provided the original author(s) and the copyright owner(s) are credited and that the original publication in this journal is cited, in accordance with accepted academic practice. No use, distribution or reproduction is permitted which does not comply with these terms. 